Motrivivência $\quad$ v. 26, $\quad$ n. 42 , p. 259-262, junho/2014

http://dx.doi.org/10.5007/2175-8042.2014v26n42p259

\title{
REFLEXÃO ÉTICO-FILOSÓFICA COMO HÁBITO DO PROFISSIONAL DE EDUCAÇÃO FÍSICA
}

"Ética na Educação Física", de Claudio Luis Alvarenga Barbosa

[Petrópolis, RJ: Vozes, 2013 - Coleção Ética nas Profissões]

Eliane Dolce Guerriero?

\section{RESUMO}

O presente texto é uma resenha da obra mencionada, na qual o autor se propõe a analisar histórica e filosoficamente o Código de Ética da Educação Física², elaborado pelo Conselho Federal de Educação Física (CONFEF), explorando suas lacunas e a ideologia implicada, além de discorrer sobre a reflexão ético-filosófica.

Palavras-chave: Ética profissional; Educação Física; CONFEF.

1 Mestranda em Educação. PROGEPE UNINOVE, São Paulo, Brasil.

E-mail: elianeguerriero@hotmail.com

2 BRASIL. Resolução 56, de 08/07/03. Dispõe sobre o código de ética dos profissionais de Educação Física registrados no sistema CONFEF/CREFs (Conselhos Regionais de Educação Física). Diário Oficial da República Federativa do Brasil, Brasília, DF, Seção 1, n. 235, p. 122, 03/12/03. 
Claudio Luis de Alvarenga Barbosa é professor da Universidade Federal Rural do Rio de Janeiro (UFRRJ), docente do Departamento de Educação e Sociedade, doutor em Educação pela Universidade Federal Fluminense (UFF).

A teorização crítica realizada sobre este documento está pautada na diferenciação entre ética e moral, posto que, sob o ponto de vista do autor, o referido Código reúne um conjunto de regras de comportamento dos profissionais de Educação Física em seus diversos espaços de atuação, o que é diferente de uma reflexão filosófica acerca destes comportamentos, que têm tempo e espaço definidos.

Tal conjunto de regras responde aos interesses de grupos que detém o poder econômico e, portanto, estabelecem uma ética unilateral. A própria redação do Código não foi fruto de discussão. A imposição veio pelo estabelecimento de uma "comissão de ética profissional", que seria responsável pelo documento, e que foi instituída após a promulgação do Código. No decorrer do texto, o autor questiona várias vezes a autodenominação do CONFEF como entidade representativa da profissão.

Sob a perspectiva positiva, o Código apresenta a abertura da discussão política da atuação do profissional de Educação Física e a prática da reflexão ética cotidiana.

O livro está dividido em quatro partes reveladas na Introdução: a primeira parte, intitulada "O Código de Ética da Educação Física", apresenta a resolução que trata do Código de Ética da Educação Física e seu anexo, ambos integralmente; a segunda parte, "A Formação do Código de Ética dos Profissionais de Educação Física", trata de explorar o Código: analisar sua história, sua relação com o CONFEF e os CREFs (Conselhos Regionais de Educação Física), seus aspectos negativos e positivos, além de dissertar sobre o universo simbólico do "juramento profissional" e sobre os conceitos trabalho e prática profissional; na terceira parte, "Princípios Fundamentais da Ética para a Educação Física", o autor discute os princípios, as concepções e o conceito de ética (discernindo-a de moral), e a relação entre Educação Física e ética aplicada; a quarta e última parte "Aspectos da Ética Aplicada à Educação Física" traz uma proposta de ética aplicada à Educação Física Escolar, ao ambiente de trabalho da academia e à pesquisa.

$\mathrm{O}$ autor discute de maneira clara a incoerência entre um documento de função punitiva e intenções obscuras e a reflexão filosófica (de fato) sobre ética e moral. Com efeito, de nada vale impor regras de conduta e não propiciar o debate ético-político profissional, ou exigir o registro para exercer a profissão e não propor disciplinas de cunho filosófico na graduação. A crítica do autor à arbitrariedade do CONFEF é legítima e urgente, apontando ações e exigências ${ }^{3}$ do CONFEF como incompatíveis à reflexão ética.

3 Como, por exemplo: obrigatoriedade do registro profissional para o exercício do magistério; afronta às universidades quanto à formação do profissional quando, sem fundamentos, se autodenomina legitimadora da profissão; privilégio de um pensamento mercantilista, focado na disputa pelo poder; o "crescente anseio de consolidar sua posição de pretenso 'guardião' da regulamentação profissional" (p. 29); as persistentes tentativas de envolvimento no exercício da profissão, criando fóruns nacionais e regionais, com a justificativa de novas demandas do mercado de trabalho. 
É importante destacar o persistente discurso do autor sobre o sentido social da prática profissional; o compromisso moral do exercício da profissão e a fixação de raízes filosóficas no estudo da Educação Física.

Algumas inquietações surgem na análise desta obra. A confusão conceitual existente há muitas décadas na Educação Física (diferenças entre a prática profissional do professor de Educação Física Escolar e o professor de ginástica em academia, ou mesmo um preparador físico num clube, por exemplo) aparece em diversos momentos do texto.

Segundo o autor, em todos segmentos da Educação Física (apenas excetuando os pesquisadores de fisiologia e biomecânica) pode-se falar em "aluno e professor". Esta generalização acaba equivalendo o sentido social do trabalho do professor de academia e do professor de Educação Física escolar. Ora, a diferença é grande: pretende-se, na escolarização formal, através de situações de aprendizagem, levar o aluno a análise crítica do mundo e sua emancipação, e isso não se aplica a uma academia, na qual o objetivo do "aluno" varia de sociabilização à aquisição/manutenção bem-estar.

Pela leitura do texto, fica sim entendido que a intenção é "abranger a totalidade dos profissionais de Educação Física" (p. 54), porém o que se consegue é reforçar a crise de identidade dessa área de conhecimento. Apesar disso, o autor mostra preocupação em discernir iniciação esportiva dos conteúdos da Educação Física: "para esse grupo (de professores presos a uma tradição), a iniciação esportiva está para a Educação Física Escolar assim como a ética está para a filosofia" (p. 94).

É plausível também afirmar que o exemplo de ética aplicada à Educação Física mencionado na obra (no capítulo específico sobre ética ambiental como fundamento da Educação Física nas escolas técnicas agrícolas) não é apropriado por ser um caso demasiadamente particular, mesmo o autor ciente desta especificidade. Segundo o Censo Escolar 20124, o ensino profissionalizante na área de agropecuária realizou $6,6 \%$ das matrículas em educação profissional de instituições públicas de todo país. É sabido que o exemplo torna clara a necessidade de mapeamento da Cultura Corporal da comunidade (especificações curriculares de acordo com a realidade local), e que é indispensável abordar a temática relacionada ao meio-ambiente, mas é possível estabelecer a relação entre Educação Física e meio-ambiente por outro caminho, não tão óbvio quanto o exemplo utilizado pelo autor, e muito mais abrangente - como a discussão sobre o consumismo citada apenas no fim deste capítulo: "uma ética ambiental rejeita os ideais de uma sociedade materialista, na qual o sucesso é medido pelo número de bens consumidos que alguém é capaz de acumular" (SINGER, 1998, apud BARBOSA, p. 103), e ainda como também o faz no capítulo 6, anterior ao supracitado, no qual o autor discorre com excelência sobre ética ambiental e sobre as relações entre sociedade e ambiente, afirmando que o homem deve responsabilizar-se sobre o planeta. 
Ao finalizar o texto, o autor extrai seu principal sentido: não sendo possível refletir sobre a totalidade da moral, pela moralidade ser um contínuo de transformação, é necessário refletir sobre esse processo, que deve se tornar um hábito no exercício profissional da Educação Física: "assumir a reflexão ético-filosófica como prática constante" (p. 127). Este hábito deve ser incorporado desde a formação do profissional. Um grande passo nessa direção, além da leitura deste texto, seria a consolidação da filosofia no currículo de graduação em Educação Física.

\title{
“ETHICAL-PHILOSOPHICAL REFLECTION AS A HABIT OF PHYSICAL EDUCATION PROFESSIONAL"
}

\begin{abstract}
This thesis is a review of the work mentioned, in which aims to analyze historically and philosophically the Code of Ethics of Physical Education, developed by Federal Council of Physical Education (CONFEF), exploring their loopholes and ideology involved, and discuss the ethical reflection and philosophical.
\end{abstract}

Key-words: Professional ethics; Physical Education; CONFEF

Recebido em: setembro/2013 Aprovado em: março/2014 